Resumen por el autor, James Stuart Plant.

Instituto Wistar de Anatomía y Biología.

Factores que influyen en el comportamiento del cerebro de la rata albina en el liquido de Müller.

El cerebro de la rata albina sufre un cambio típico cuando se "fija" en el liquido de Müller, compuesto de 2 por ciento de bicromato potásico y 10 por ciento de sulfato sódico. El cerebro aumenta rápidamente de peso, al que sigue una pérdida de peso lenta y continua, hasta que al cabo de setenta y cinco dias, al pesar el cerebro se comprueba que pesa de 20 a 30 por ciento más que el cerebro fresco. 1. La edad es la principal condición que influye en esta reacción del liquido de Müller. Los cerebros de ratas viejas aumentan más en peso y retienen este aumento durante los setenta y cinco dias. 2. El peso inicial del cerebro, o sea su tamaño, es la condición de más importancia después de la apuntada más arriba. Del mismo modo que con los cerebros de la misma edad, los cerebros más ligeros aumentan más de peso durante la primera parte de su permanencia en el liquido de Müller. Esta diferencia disminuye gradualmente y desaparece al cabo de los setenta y cinco dias. 3. La edad próximamente semejante (entre ciertos límites) tiene casi el mismo valor determinante que la igualdad de edad. 4. El sexo es un factor sin importancia, del mismo modo que la composición hereditaria (relación dentro de un tronco determinado).

Translation by José F. Nonidez

Carnegie Institution of Washington 


\section{FACTORS INFLUENCING THE BEHAVIOR OF THE BRAIN OF THE ALBINO RAT IN MÜLLER'S FLUID}

\section{JAMES STUART PLANT}

Neurological Laboratory of The Wistar Institute of Anatomy and Biology

The brain of the albino rat, placed for a period in Müller's fluid, exhibits a typical change. In the course of time it not only hardens, but also markedly increases in weight. There is a rapid increase to a maximum in about one week's time, after which there is a slow, steady loss until the seventy-five day weighing, at which time the brain weighs 20 to 30 per cent more than when fresh. It was thought that changes in this typical curve might be induced in the brains of rats previously anesthetized for prolonged periods, and it was hoped that this criterion would be more delicate than the microscopic or analytic tests which had, so far, failed to demonstrate a change. Thework was done at The Wistar Institute of Anatomy during the academic year 1913-1914.

\section{PLAN}

The main question of the effect of the anesthetic on the typical curve remains unanswered. From the start, however, it was recognized that various factors influenced the reaction of 'control' brains to Müller's fluid--factors which are inherent in the material. It is these factors and their influence on the reaction with which the present paper deals.

\section{PROCEDURE}

The brains studied belonged to 'stock' albino rats. The animals were killed with ether and the brains quickly removed with every care not to damage them. They were immediately weighed and then suspended in 50 cc. of Müller's fluid. The 
whole was kept in a black cardboard case in a dark closet. Subsequent weighings were as follows. The brain was removed from the solution and placed for about ten seconds on a dry piece of filter-paper. The string by which it had been suspended was during this time removed. The brain was then placed on a watch-glass and immediately weighed. It was returned to the Müller's fluid as quickly as possible. The watch-glass was then weighed. Reweighings were carried out at 24 hours, and at 7 , 14,30 , and 75 days after killing the rat. On completion of the weighings the percentage of water in the brain at the final weighing was determined. This procedure involved placing the brain, immediately after its last weighing, in a small glass vial of known weight. This was kept in a drying oven (temperature, $97^{\circ}$ ) for one week. On removal, the vial was cooled in a desiccator at room temperature and weighed.

The Müller's fluid used was made up in $1000 \mathrm{cc}$. lots. To 25 grams of potassium bichromate c. p. and 10 grams of sodium sulphate c. p. was added 1000 cc. of distilled water. Time was given for dissolving the salts and, after thorough agitation, the solution was divided into two $500 \mathrm{cc}$. lots and kept for one month before being used. In every instance 'pairs' of brains were fixed in fluid from the same bottle. The Müller's fluid was always kept in a dark closet.

No attempt was made to control the temperature during the reaction of fixation other than that all specimens were kept in the same dark closet at room temperature. Thus the results may be considered as comparable.

Necessarily our original results are in terms of absolute weights and absolute gains. In the presence of so diverse initial weights it seemed, however, best to state all gains in weight as percentages of the original weight. This makes the data comparable. Corresponding to this, all statements of the relation of one brain's gain to that of another are in terms of a percentage of the percentages of gain of the heavier brain. This leads to higher figures, in the relations of the gains, than would be the case were the actual differences between the absolute gains stated. 


\section{OBSERVATIONS}

If we consider the brains of pairs (rats of the same age, sex, and litter, i.e., as similar as possible), there appears a very distinct tendency for the brains of older rats to gain more in Müller's fluid than do those of the younger rats. Table 1 presents fifteen pairs arranged on the basis of their age. In ten of the fourteen possible comparisons the brains of older rats gain more in twentyfour hours. Also in ten of the comparisons the older brains

TABLE 1

Percentages of gain of pairs of albino rat brains arranged according to age and weighed at intervals from twenty-four hours to seventy-five days

\begin{tabular}{|c|c|c|c|c|c|c|c|c|}
\hline \multirow{2}{*}{$8 E x$} & \multirow{2}{*}{$\mathbf{A Q E}$} & \multicolumn{2}{|c|}{ INITIAL WEIGHT } & \multicolumn{5}{|c|}{$\begin{array}{l}\text { AVERAGE PERCENTAGES OF GAIN OF BOTH BRAINS } \\
\text { IN MÜLLERE FLUID }\end{array}$} \\
\hline & & 1 & 2 & 24 hours & 7 days & 14 days & 30 days & 75 days \\
\hline & days & orams & grams & & & & & \\
\hline$q$ & 52 & 1.465 & 1.368 & 19.0 & 28.2 & 26.2 & 23.5 & 22.9 \\
\hline \% & 55 & 1.615 & 1.578 & 20.8 & 32.1 & 28.1 & 26.8 & 25,4 \\
\hline$\sigma^{7}$ & 57 & 1.757 & 1.671 & 20.6 & 31.2 & 26.0 & 25.9 & 25.7 \\
\hline$\sigma^{7}$ & 59 & 1.635 & 1.519 & 21.2 & 33.1 & 29.9 & 27.0 & 26.7 \\
\hline $0^{x}$ & 61 & 1.834 & 1.715 & 18.0 & 32.2 & 28.0 & 25.9 & 25.0 \\
\hline q & 61 & 1.699 & 1.581 & 20.0 & 29.5 & 27.3 & 24.1 & 23.0 \\
\hline $0^{x}$ & 62 & 1.490 & 1.477 & 18.6 & 31.8 & 28.3 & 25.3 & 24.4 \\
\hline $0^{7}$ & 62 & 1.662 & 1.656 & 19.3 & 28.2 & 24.6 & 23.1 & 22.7 \\
\hline$q$ & 62 & 1.497 & 1.496 & 20.5 & 31.7 & 29.1 & 25.7 & 25.3 \\
\hline $0^{x}$ & 62 & 1.831 & 1.699 & 20.8 & 32.8 & 30.8 & 28.0 & 27.8 \\
\hline 우 & 64 & 1.677 & 1.606 & 20.9 & 32.0 & 28.6 & 26.2 & 25.7 \\
\hline $0^{x}$ & 67 & 1.651 & 1.587 & 21.7 & 32.6 & 29.7 & 26.6 & 26.4 \\
\hline$q$ & 72 & 1.610 & 1.492 & 27.6 & 33.6 & 30.7 & 27.9 & 26.7 \\
\hline $0^{x}$ & 160 & 1.791 & 1.752 & 25.1 & 37.2 & 35.8 & 32.8 & 32.2 \\
\hline $0^{7}$ & 218 & 2.008 & 1.824 & 28.3 & 40.0 & 38.6 & 35.7 & 34.6 \\
\hline
\end{tabular}

gain more in seventy-five days, though this does not in every case involve the same comparisons as were favorable to the older rats at the twenty-four hour weighing. Table 2 presents a summary of the data of table 1 . The averaged figures for the youngest three pairs and for the oldest three pairs are given. The data show that age is a very important factor in the reaction of the brain of the albino rat to Müller's fluid.

Brain weight increases as a function of age, and there exists between these two characters a very high coefficient of correla- 
TABLE 2

Percentages of gain of averaged entries of table 1

\begin{tabular}{|c|c|c|c|c|c|c|c|c|}
\hline \multirow{2}{*}{ PAIRS AVERAGED } & \multirow{2}{*}{$\triangle G E$} & \multicolumn{2}{|c|}{ INITIAL WEIGHT } & \multicolumn{5}{|c|}{$\begin{array}{l}\text { AYERAGE PERCENTAGES OF GAIN IN } \\
\text { MÜLLERS FLUID }\end{array}$} \\
\hline & & 1 & 2 & $\begin{array}{c}24 \\
\text { hours }\end{array}$ & $\begin{array}{c}7 \\
\text { days }\end{array}$ & $\begin{array}{c}14 \\
\text { days }\end{array}$ & $\begin{array}{c}30 \\
\text { days }\end{array}$ & $\begin{array}{c}75 \\
\text { days }\end{array}$ \\
\hline & days & grams & grams & & & & & \\
\hline First three entries & 55 & 1.612 & 1.539 & 20.1 & 30.5 & 26.8 & 25.4 & 24.7 \\
\hline Last three entries. & 150 & 1.803 & 1.689 & 27.0 & 37.0 & 35.0 & 32.1 & 31.2 \\
\hline
\end{tabular}

tion. If we make a comparison of the individual brains of the respective pairs involved in table 1 , however, we may study the effect of initial brain weight in animals of like age. The data are given in table 3 . In place of the percentage of gain of the lighter brain there is entered at the several columns marked 'Per cent deviation of 2'--under 'Time in Müller's fluid'-only the relation of that percentage to the percentage of gain of the heavier brain. Of the fifteen pairs involved, it will be noted that in twelve the lighter brain gains more in the first twentyfour hours (represented by a + in the second column). Also in twelve of the fifteen pairs, the heavier brain later 'catches up' - that is, the relative gain of the heavier brain is greater at seventy-five days than at one day. This phenomenon is clearly demonstrated in the 'averages' at the bottom of the table. The results may be summarized as follows:

\begin{tabular}{|c|c|c|c|c|c|}
\hline & $1 \mathrm{DAY}$ & 7 DAYS & 14 DAYS & 30 DAYS & $75 \mathrm{DAYS}$ \\
\hline Average difference. & +3.9 & +1.5 & +1.3 & +1.2 & +0.2 \\
\hline Standard deviation. & \pm 6.1 & \pm 3.9 & \pm 5.0 & \pm 5.2 & \pm 6.5 \\
\hline
\end{tabular}

Thus it appears that the lighter brain gains more in the early part of the stay in Müller's fluid, but that this difference practically disappears at the seventy-five-day weighing. It is to be noted that the standard deviations are lowest at the seven-day weighing. This seems to represent the period of least individual variation. As this represents the time of maximum increase, we may consider that as the more stable period in the 
curves and think of the rise and fall in percentage of increase as periods more subject to individual variation.

While increasing age presupposes increase in brain weight, it is apparent that these two-age and brain weight-act as opposing factors in the determination of the reaction of the brain to Müller's fluid. That is, the older brains (these are heavier)

TABLE 3

The effect of initial brain weight-albino rat-on the percentage of gain of paired brains. Pairs arranged according to age. Deviation of the lighter brain

\begin{tabular}{|c|c|c|c|c|c|c|c|c|c|c|c|c|c|}
\hline \multirow{3}{*}{ SEX } & \multirow{3}{*}{ AGE } & \multicolumn{2}{|c|}{$\begin{array}{l}\text { INITIAL } \\
\text { WEIGHT }\end{array}$} & \multicolumn{10}{|c|}{ TIME IN MÜLLERS FLUID. PERCENTAGES OF GAIN } \\
\hline & & \multirow[b]{2}{*}{1} & \multirow[b]{2}{*}{2} & \multicolumn{2}{|c|}{24 hours } & \multicolumn{2}{|c|}{7 days } & \multicolumn{2}{|c|}{14 days } & \multicolumn{2}{|c|}{30 days } & \multicolumn{2}{|c|}{75 days } \\
\hline & & & & 1 & $\begin{array}{c}\text { Per } \\
\text { cent de- } \\
\text { viation } \\
\text { of } 2 \\
\end{array}$ & 1 & $\begin{array}{c}\text { Per } \\
\text { cent de- } \\
\text { viation } \\
\text { of } 2 \\
\end{array}$ & 1 & $\left|\begin{array}{c}\text { Per } \\
\text { cent de- } \\
\text { viation } \\
\text { of } 2\end{array}\right|$ & 1 & $\mid \begin{array}{c}\text { Per } \\
\text { cent de- } \\
\text { viation } \\
\text { of } 2\end{array}$ & 1 & $\begin{array}{c}\text { Per } \\
\text { cent de- } \\
\text { viation } \\
\text { of } 2\end{array}$ \\
\hline & days & grams & grams & & & & & & & & & & \\
\hline$q$ & 52 & 1.465 & 1.368 & 19.3 & -2.8 & 27.9 & +2.1 & 26.8 & -4.2 & 24.1 & -4.9 & 23.5 & -5.7 \\
\hline \% & 55 & $|1.615|$ & 1.578 & 20.4 & +3.6 & 31.7 & +2.5 & 27.7 & +2.6 & 25.8 & $3+8.2$ & 25.1 & +2.1 \\
\hline $0^{7}$ & 57 & 1.757 & 1.671 & 19.5 & +11.1 & 30.5 & +4.1 & 25.5 & +4.1 & 25.2 & $2+5.1$ & 24. & $3+6.8$ \\
\hline$\sigma^{7}$ & 59 & $1.635 \mid$ & $1.519 \mid$ & 20.5 & +6.5 & 33.0 & +0.2 & 30.3 & -2.2 & 27.4 & -2.4 & 27.2 & -4.0 \\
\hline \% & 61 & $|1.699|$ & 1.581 & 18.8 & +13.3 & $28.7 \mid$ & +6.0 & $\mid 26.2$ & +8.8 & 23.3 & +7.0 & $\mid 21.6$ & +12.9 \\
\hline$\sigma^{\pi}$ & 61 & 1.834 & 1.715 & 17.9 & +1.3 & $31.5 \mid$ & +4.2 & 27.5 & +4.12 & 25.4 & +3.8 & 24.7 & +1.8 \\
\hline$\sigma^{\top}$ & 62 & $1.490 \mid$ & $|1.477|$ & 18.8 & -1.8 & $32.4 \mid$ & -3.4 & 29.3 & -7.2 & 26.3 & $3 \mid-7.3$ & 25.0 & -4.8 \\
\hline q & 62 & $1.497 \mid$ & $1.496 \mid$ & 20.5 & +0.3 & 31.4 & +1.7 & $28.7 \mid$ & $\mid+2.12$ & 25.9 & -0.7 & 25.1 & +2.1 \\
\hline $0^{7}$ & 62 & $|1.662|$ & 1.656 & .19 .2 & +0.9 & 27.4 & +6.0 & 23.7 & $|+7.2| 2$ & 22.6 & +4.4 & 22.2 & +4.5 \\
\hline$\sigma^{x}$ & 62 & 1.831 & 1.699 & 18.9 & +19.6 & 31.5 & +8.4 & 29.4 & +9.8 & 26.7 & +10.3 & 26.3 & +11.4 \\
\hline 우 & 64 & $|1.677|$ & $\mid 1,606$ & 21,1 & -1.2 & $32.6 \mid$ & -3.5 & 29.4 & $\mid-4.9$ & 26.8 & $3 \mid-4.3$ & 26.2 & -4.3 \\
\hline$\sigma^{7}$ & 67 & $|1.651|$ & $|1.587|$ & 21.6 & +0.8 & 33.3 & -4.6 & 30.5 & -5.1 & 27.3 & $|-4.7|$ & 28.0 & -11.2 \\
\hline q & 72 & 1.610 & 1.492 & 26.9 & $\mid+5.2$ & 33.3 & +1.3 & $30,4 \mid$ & +1.7 & 28.3 & -2.3 & $\mid 27.4$ & -5.2 \\
\hline$\sigma^{\pi}$ & 160 & 1.791 & 1.752 & 25.0 & +0.3 & 38.0 & -4.0 & $|35.3|$ & +2.43 & 32.6 & +1.1 & 32.5 & -2.2 \\
\hline$\sigma$ & 218 & 2.008 & 1.824 & 28.0 & +2.0 & 40.1 & +1.2 & 38.5 & +0.93 & 34.8 & $3+4.9$ & 34.7 & -0.8 \\
\hline \multicolumn{2}{|c|}{$\begin{array}{l}\text { Average. } \\
\text { Standard }\end{array}$} & & & & $\begin{array}{l}+3.9 \\
\pm 6.1\end{array}$ & & $\begin{array}{l}+1.5 \\
\pm 3.9\end{array}$ & & $\begin{array}{l}+1.3 \\
\pm 5.0\end{array}$ & & $\begin{array}{l}+1.2 \\
\pm 5.2\end{array}$ & & $\begin{array}{l}+0.2 \\
\pm 6.5\end{array}$ \\
\hline
\end{tabular}

gain more than do the younger ones; yet the lighter brains gain more than do the heavier ones if we can eliminate age as a factor, as was done in table 3 . The curve of increase in weight may be considered as capable of solution into at least two curves - expressing these two factors. Age appears to be by far the more potent factor. 
A further study was made of fifty-nine brains arranged according to increasing brain weight but without regard to sex or litter. In table 4 these are arranged according to initial brain weight in three age groups. Within these grouns two phenomena are apparent (shown in the averages under the vertical column, 'Percentage difference from the following value'). These are the early greater gains for the lighter brains (this does not hold clearly for the ten brains of the youngest group where there is practically no difference); and the fact that at the seventy-fiveday weighing the lighter brains show relatively a less percentage of increase than they do at the twenty-four-hour weighing. Since these facts are just those which determine the curve when brains of rats of the same age, sex, and litter are compared, we may conclude that in the reaction of the brain to Müller's fluid:

1. Sex is negligible.

2. Inherited composition is negligible.

3. Approximate similarity of ages (the range being limited) may be considered as having the same effect as though the ages were identical.

The data on the percentage of water-in the last column of table 4--will be discussed later.

A group of four brains-all belonging to young rats-was subjected to an additional procedure. The brains, immediately upon removal, were separated into cerebrum, cerebellum, stem, and olfactory bulbs. Each part was then treated as were the whole brains of the other series. The data are given in table 5 in this way, that that percentage of the whole brain weight represented by the weight of each part at each weighing is recorded. The figures for the four brains show but slight variation, and table 5 therefore presents only the averages of the four. The relative weights of the various parts undergo considerable change in Müller's fluid, but this change is mainly consummated in the first twenty-four hours. Thus we may assume from this study that, while the relations of the various parts are altered in the fixing solution, the length of time, after the first twenty-four hours, during which the parts are subjected to this treatment, is a matter of minor import. 
TABLE 4

The effect of initial brain weight-albino rat-on the percentages of gain of brains arranged in age groups, regardless of sex or litter

\begin{tabular}{|c|c|c|c|c|c|c|c|c|c|c|}
\hline \multirow[b]{2}{*}{$\begin{array}{l}\text { INITIAL WEIGHT } \\
\text { (GRAMS) }\end{array}$} & \multirow[b]{2}{*}{$\mid \begin{array}{c}\text { NUM- } \\
\text { BER OF } \\
\text { CASES }\end{array}$} & \multirow[b]{2}{*}{$\begin{array}{c}A V E R- \\
A G E \\
A G E\end{array}$} & \multirow[b]{2}{*}{$\begin{array}{c}24 \\
\text { HOURS }\end{array}$} & \multirow{2}{*}{ 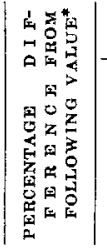 } & \multicolumn{6}{|c|}{ AYERAGE PERCENTAGES OF GAIN } \\
\hline & & & & & $\stackrel{7}{\text { days }}$ & $\begin{array}{c}14 \\
\text { days }\end{array}$ & $\begin{array}{l}30 \\
\text { days }\end{array}$ & $\begin{array}{c}75 \\
\text { days }\end{array}$ & 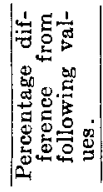 & 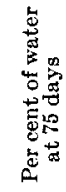 \\
\hline \multicolumn{11}{|c|}{50 to 60 days } \\
\hline $1.35-1.40$ & 1. & 52 & 18.7 & -2.8 & 28.5 & 25.7 & 22.9 & 22.2 & $|-5.6|$ & 79.3 \\
\hline $1.40-1.50$ & 1 & 52 & 19.3 & -11.1 & 27.9 & 26.8 & 24.1 & 23.5 & $\mid-11.2$ & 79.3 \\
\hline $1.50-1.60$ & 3 & 53 & 21.7 & $\mid+5.8$ & 33.2 & 29.2 & 27.5 & 26.5 & +1.2 & 80.1 \\
\hline $1.60-1.65$ & 2 & 57 & 20.5 & $|-2.2|$ & 32.3 & 29.0 & 26.6 & 26.2 & -3.0 & 79.9 \\
\hline $1.65-1.70$ & 2 & 58 & 20.9 & $|+3.2|$ & 32.8 & 28.8 & 27.7 & 27.0 & +8.7 & 80.3 \\
\hline $1.70-1.80$ & 1 & 57 & 19.5 & & 30.5 & 25.5 & 25.2 & 24.8 & & 80.3 \\
\hline Average 1.58 & 10 & 55 & 20.5 & $|-0.9|$ & 31.7 & 28.1 & 26.3 & 25.7 & $|-2.1|$ & 80.0 \\
\hline \multicolumn{11}{|c|}{60 to 70 days } \\
\hline $1.40-1.50$ & 7 & 64 & 21.7 & $\mid+1.9$ & 32.9 & 29.8 & 26.6 & 25.7 & +0.5 & 79.7 \\
\hline $1.50-1.60$ & 5 & 65 & 21.3 & -8.6 & 32.1 & 29.1 & 26.2 & 25.6 & $|-9.3|$ & 79.3 \\
\hline $1.60-1.65$ & 6 & 69 & 23.3 & $\mid+12.3$ & 34.1 & 31.5 & 28.8 & 28.2 & +10.6 & 80.2 \\
\hline $1.65-1.70$ & 11 & 68 & 20.7 & +2.9 & $31: 5$ & 28.5 & 26.0 & 25.5 & $|+3.1|$ & 79.7 \\
\hline $1.70-1.80$ & 5 & 65 & 20.1 & +8.2 & 31.6 & 28.2 & 26.4 & 24.7 & -1.8 & 80.1 \\
\hline $1.80-1.90$ & 3 & 63 & 18.6 & & 31.5 & 27.9 & 25.7 & 25.2 & & 80.7 \\
\hline Average 1.65 & 37 & 66 & 21.1 & +3.9 & 32.3 & 29.2 & 26.6 & 25.9 & +1.8 & 79.8 \\
\hline \multicolumn{11}{|c|}{180 to 240 days } \\
\hline $1.65-1.70$ & 1 & 189 & 28.7 & $|+8.5|$ & 42.4 & 39.2 & 36.1 & 35.4 & $|+9.3|$ & 81.6 \\
\hline $1.70-1.80$ & 4 & 191 & 26.5 & +2.8 & 38.2 & 36.2 & 33.2 & 32.4 & +3.2 & 80.5 \\
\hline $1.80-1.90$ & 5 & 239 & 25.7 & +8.7 & 37.6 & 36.4 & 32.4 & 31.5 & +6.1 & 80.5 \\
\hline $1.90-2.00$ & 2 & 206 & 23.7 & & 35.6 & 33.0 & 30.4 & 29.7 & & 78.4 \\
\hline Average. 1.83 & 12 & 213 & 25.9 & +6.1 & 37.9 & 36.0 & 32.7 & 31.8 & +5.6 & 80.2 \\
\hline
\end{tabular}

* The percentages were obtained originally by the use of values carried to three places. These have now been reduced to one-place numbers and there are therefore some apparent discrepancies in the percentage-difference columns. These differences, however, are not significant. 
TABLE 5

Averaged percentage weight relations of the parts of four albino rat brains during the course of their reaction to Müller's fluid

\begin{tabular}{|c|c|c|c|c|c|c|}
\hline $\mathrm{AGE}$ & $\begin{array}{c}\text { WEIGHT OF } \\
\text { WHOLE BRAIN } \\
\text { AVERAGE OF } \\
\text { FOUR }\end{array}$ & $\begin{array}{c}\text { PERCENTAGE } \\
\text { REPRE- } \\
\text { SENTED BY } \\
\text { CERERRUM }\end{array}$ & $\begin{array}{l}\text { PERCENTAGE } \\
\text { REPRE- } \\
\text { SENTED BY } \\
\text { STEM }\end{array}$ & $\mid \begin{array}{c}\text { PERCENTAGE } \\
\text { REPRE- } \\
\text { SENTED BY } \\
\text { CEREBELLUM }\end{array}$ & $\mid \begin{array}{c}\text { PERCENTAGE } \\
\text { REPRE- } \\
\text { SENTED BY } \\
\text { OLFACTORY } \\
\text { BULBS }\end{array}$ & $\begin{array}{c}\text { TIME IN } \\
\text { MULLER'B } \\
\text { FLUID }\end{array}$ \\
\hline 52 & $\begin{array}{l}1.610 \\
2.127 \\
2.171 \\
2.094\end{array}$ & $\begin{array}{l}65.17 \\
63.10 \\
64.82 \\
63.77\end{array}$ & $\begin{array}{l}17.40 \\
17.68 \\
17.21 \\
17.76\end{array}$ & $\begin{array}{l}13.80 \\
15.08 \\
14.33 \\
14.72\end{array}$ & $\begin{array}{l}3.63 \\
4.14 \\
3.63 \\
3.75\end{array}$ & $\begin{array}{l}\text { Initial } \\
24 \text { hours } \\
7 \text { days } \\
30 \text { days }\end{array}$ \\
\hline \multicolumn{2}{|c|}{$\begin{array}{c}\text { Difference between per- } \\
\text { centages at initial and } \\
24 \text {-hour weighing....... } \\
\text { Difference between per- } \\
\text { centages at } 24 \text {-hour } \\
\text { and } 30 \text {-day weighing... }\end{array}$} & -2.07 & +0.28 & +1.28 & $\begin{array}{l}+0.51 \\
-0.39\end{array}$ & \\
\hline
\end{tabular}

\section{WATER RELA'TIONS}

We have studied the water relations after seventy-five days in fifty-nine whole brains and after thirty days in the parts of three brains. There is evidently, in the reaction of the brain to the Müller's fluid, a deposition of salts in the brain tissue. This is shown in table 6. Part A deals with the fifty-nine wholebrains; Part B with the parts of three brains (all belonging to young females). The deposition of salts at the end of seventy-five days in the whole brain is from 3.9 per cent to 4.3 per cent of the total water of the brain despite the fact that the salts in Müller's fluid are present in a concentration of but 3.5 per cent. This shows a deposition of salts in the tissues. If, in addition, there is some diffusion of solids from the brain to Müller's fluidand, from inspection, this appears to be the case-the percentage of salts deposited must be even higher than that indicated by the figures given.

The final percentage of water in a given brain at the seventyfive-day weighing is only slightly greater than that of a fresh brain belonging to a rat of the same age, sex, and litter. In view of the 20 to 30 per cent net increase in weight in Müller's 
TABLE 6

Part A. Water relations at the seventy-five day weighing of fifty-nine whole brains (see table 4)

\begin{tabular}{|c|c|c|c|}
\hline & $\begin{array}{c}\text { UNDER } 60 \\
\text { DAYS }\end{array}$ & $\begin{array}{c}60 \text { To } 120 \\
\text { DAYY }\end{array}$ & $\begin{array}{c}\text { OVER } 120 \\
\text { DA Y Y S }\end{array}$ \\
\hline Average fresh brain weight.. & 1.582 & 1.651 & 1.826 \\
\hline Percentage of water (from Donaldson, '16). & $79.1 \%$ & $78.9 \%$ & $78.1 \%$ \\
\hline 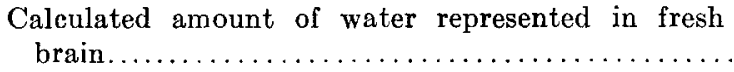 & 1.252 & 1.303 & 1.426 \\
\hline Final brain weight.............. & 1.988 & 2.078 & 2.407 \\
\hline Final amount of water. & 1.590 & 1.659 & 1.932 \\
\hline Percentage of water-observed. & $80.0 \%$ & $79.8 \%$ & $80.2 \%$ \\
\hline Increase in weight due to water, gms. & 0.338 & 0.356 & 0.506 \\
\hline Increase in weight due to salts, gms.. & 0.068 & 0.071 & 0.075 \\
\hline Percentage of salts in total increase in weigh & $16.6 \%$ & $16.7 \%$ & $13.0 \%$ \\
\hline Percentage of salts in the total water in brain & $4.2 \%$ & $4.3 \%$ & $3.9 \%$ \\
\hline
\end{tabular}

Part B. Water relations at the thirty-day weighing of parts of three brains

\begin{tabular}{|c|c|c|c|c|}
\hline & CEREBRUM & STEM & $\begin{array}{l}\text { C.'PE- } \\
\text { BELLUM }\end{array}$ & $\begin{array}{l}\text { OLFAC- } \\
\text { TORY } \\
\text { BULBS }\end{array}$ \\
\hline Average fresh brain weight. & 1.097 & 0.292 & 0.235 & 0.058 \\
\hline Percentage of water (from Donaldson, '16).. & $80.0 \%$ & $76.1 \%$ & $79.7 \%$ & $82.3 \%$ \\
\hline 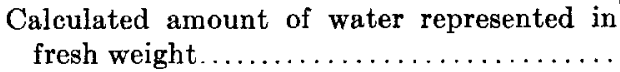 & 0.878 & 0.222 & 0.188 & 0.048 \\
\hline Final weight.... & 1.403 & 0.386 & 0.329 & 0.078 \\
\hline Final amount of water. & 1.139 & 0.301 & 0.266 & 0.067 \\
\hline Percentage of water-observed........... & $81.2 \%$ & $77.9 \%$ & $80.8 \%$ & $85.6 \%$ \\
\hline Increase in weight due to water, gms. & 0.261 & 0.079 & 0.078 & 0.019 \\
\hline Increase in weight due to salts, gms... & 0.044 & 0.016 & 0.015 & 0.001 \\
\hline $\begin{array}{l}\text { Percentage of salts in total increase in weight } \\
\quad(\text { for total brain } 14.8 \%) \ldots \ldots \ldots \ldots \ldots \ldots\end{array}$ & $14.5 \%$ & $16.4 \%$ & $16.4 \%$ & $4.9 \%$ \\
\hline $\begin{array}{l}\text { Percentage of salts in total water in the part } \\
\quad(\text { for total brain } 4.3 \%) \ldots \ldots \ldots \ldots \ldots \ldots \ldots\end{array}$ & $3.9 \%$ & $5.0 \%$ & $5.8 \%$ & $1.5 \%$ \\
\hline
\end{tabular}

fluid, this seems a striking fact, though where the initial percentage of water is so high, it is evident that it takes a relatively large difference in the absolute water content to markedly affect the percentage value.

In the three brains divided into their parts the salts are deposited in the following percentages after thirty days: 
Cerebellum............................. 5.8 per cent

Stem................................ 5.0 per cent

Cerebrum.................................. 3.9 per cent

Olfactory bulbs............................ 1.5 per cent

Average of whole brain ...................... 4.3 per cent

With the exception of the cerebellum, the percentage of salts deposited is in direct relation with the proportion of myelin in the part involved. As none of the parts were washed, it may well be that the interstices of the cerebellum were the site of large deposits of salts, a physical factor which may account for this anomalous result.

\section{CONCLUSIONS}

General reaction of the brain to Müller's fluid, or type curves. The brain of the albino rat undergoes a typical change when 'fixed' in Müller's fluid (2.5 per cent potasshum bichromate and 1 per cent. sodium sulphate). There is a rapid increase in weight followed by a slow, steady loss until at the seventy-fiveday weighing the brain weighs 20 to 30 per cent more than when fresh.

Factors affecting this reaction, or components of the type curve.

1. Age is the main condition controlling this reaction to Müller's fluid. The brains of older rats gain more and retain this higher relative gain throughout the seventy-five days.

2. Initial brain weight, or size, is the condition of next importance. As between brains of like age the lighter brains gain more during the earlier part of their stay in Müller's fluid. This difference is gradually lessened, and it disappears at the seventyfive-day weighing.

Thus, while age and initial brain weight are highly correlated, they constitute factors which, when taken alone, influence in opposite ways the reaction of the brain to Müller's fluid. The early greater increase of the smaller brain of two rats of the same age may be due to one or both of the following factors:

$a$. If we consider the brain as a sphere and the fluids as penetrating at a fixed rate, then in the smaller brain a slightly greater 
proportion of the brain will be penetrated-that is, swollen by the fixing fluid-at any given instant in the early part of the reaction. This would give a more rapid enlargement in the smaller brain.

$b$. The smaller brain has a higher percentage of water which might make diffusion more rapid. If this is a controlling factor, the matter of a higher percentage of water must be of more immediate importance than is that of a lesser percentage of myelin.

3. Approximately similar age (the range being limited) has nearly the same determining value as equality of age.

4. Sex is a negligible factor, as is also inherited composition (relationship within a given strain).

\section{FINAL WATER RELATIONS}

The increase in weight is due mainly to the taking up of water, but the percentage of salts deposited in the fixed tissues is much greater than that in the fixing fluid. With the exception of the cerebellum, the deposition of salts is proportional to the myelin present in the part of the brain.

\section{RELATION OF RESULTS}

The curve of reaction of 'control' brains to Müller's fluid is evidently of such constancy in character as to make it a satisfactory criterion for a judgment as to alterations produced in the brain by various experimental procedures. It seems that in problems involving changes not available to such microscopic or analytical tests as we have, this reaction might furnish a valuable means of study. It appears from the foregoing results that when tests are made for the experimental modification of the response of the brain to Müller's fluid, it is necessary to have the test and control brains of the same age and, in those cases in which the brains differ in weight, to allow sufficient time for the compensation of this difference. 


\section{LITERATURE}

While various observations bearing upon this problem have been made, none have employed exactly our experimental procedure. Various solutions of potassium bichromate have been used-Donaldson ('94), Fish ('93), and King ('10) - but a study in the changes in the reaction to Müller's fluid has not been made. A similar study was carried out by Hrdlicka ('06) in which various formalin preparations were used as fixing reagents. The effect of age upon this reaction has been discussed in a general way-Donaldson ('94) and King ('10)-but it seems that the extent of its control over the reaction has not been previously stated.

\section{BIBLIOGRAPHY}

Donaldson, H. H. 1894 Preliminary observations on some changes caused in the nervous tissues by reagents commonly employed to harden them. Jour. Morph., vol. 9.

1916 A revision of the percentage of water in the brain and in the spinal cord of the albino rat. Jour. Comp. Neur., vol. 27.

FISH, P. A. 1893 Brain preservation with a résumé of some old and new methods. Wilder Quarter-Century Book, Ithaca.

Hrdlicks, A. 1906 Brains and brain preservatives. Proc. U. S. Nat. Museum, vol. 30 .

Fing, H. D. 1910 The effects of various fixatives on the brain of the albino rat, with an account of a method of preparing this material for a study of the cells in the cortex. Anat. Rec., vol. 4. 